\title{
Relevance of IT Integration into Teaching to Learning Satisfaction and Learning Effectiveness
}

\author{
Shiuan-Ying Huang ${ }^{1, *}$ \\ ${ }^{1}$ Department of Applied Foreign Languages, School of Management, Takming University of Science and Technology, \\ Taipei, Taiwan \\ *Correspondence: Department of Applied Foreign Languages, School of Management, Takming University of \\ Science and Technology, No.56, Sec.1, Huanshan Rd., Neihu District, Taipei City, Taiwan 11451, R.O.C. Tel: \\ 886-2-2658-5801. E-mail: hsy@takming.edu.tw
}

Received: January 15, 2014 Accepted: February 21, 2014 Online Published: March 3, 2014

doi:10.5430/wje.v4n2p1

URL: http://dx.doi.org/10.5430/wje.v4n2p1

\begin{abstract}
The main purpose of this study is to verify and understand the effects of IT integration into teaching by colleges and vocational schools in Taiwan on learning effectiveness, with learning satisfaction as a mediator. This paper adopts stratified sampling on the administrative supervisors and teachers (i.e. population) in Taiwanese colleges and vocational schools. Structural equation modelling (SEM) is performed to verify the overall model and goodness-of-fit of the structural model and the measurement model. The research results suggest: (1) IT integration into teaching yields significantly positive influence on learning effectiveness; (2) IT integration into teaching exhibits significantly positive influence on learning satisfaction; and (3) Learning satisfaction has a significantly positive influence on learning effectiveness. In sum, learning satisfaction exhibits a certain degree of mediating effects. The research findings can serve as a reference to the administrative supervisors and teachers in Taiwanese colleges and vocational schools regarding the importance and benefits of IT integration into teaching to learning satisfaction and learning effectiveness of students.
\end{abstract}

Keywords: IT integration into teaching; learning satisfaction; learning effectiveness

\section{Introduction}

Teaching has to adjust to the needs of social development. Modern teaching techniques, interactive teaching methods and personalized teaching contents are replacing the old-fashioned rigid model of teaching. The aim of modern education is to develop innovative spirits for students so that they can think independently, make sound judgments and eventually resolve problems. Such capabilities will stay with the students for the rest of their lives. Existing papers on IT integration into teaching, learning satisfaction and learning effectiveness tackle different issues but generally focus on learning facilities (i.e. electronic whiteboards, projectors and computerized teaching platforms), teachers, curricula, learning attitude, motivations, interest and learning effectiveness of students (i.e. school grades, the number of professional certificates they obtain and the results of external examinations).

Learning satisfaction and learning attitude are both the key metrics to evaluate learning effectiveness. There are many factors that affect learning satisfaction and learning effectiveness of the students. In addition to personal factors of students, teacher, curriculum and learning environment can all be part of the equation. In fact, depending on different research purposes and environments, scholars may focus on different factors as their research topic. Nonetheless, the effects of IT integration to teaching and learning effectiveness are an important issue worthy of continuous tests and verifications. Meanwhile, the constant updates in IT integration into teaching or teaching techniques create a solid foundation for teaching effectiveness (for teachers) and learning effectiveness (for students), and enhance the level of satisfaction and learning effectiveness of students. Therefore, this paper refers to the exploratory studies in Taiwan and overseas and seeks to test and understand the effects of IT integration into teaching on learning effectiveness of the students, with learning satisfaction as the mediator. This paper sets out the following three research purposes: 
1. To verify whether IT integration into teaching has significantly positive effects on learning effectiveness;

2. To verify whether IT integration into teaching has significantly positive effects on learning satisfaction;

3. To verify whether learning satisfaction has significantly positive effects on learning effectiveness.

\section{Literature Review}

The key dimensions of this study are IT integration into teaching, learning satisfaction and learning effectiveness. Below is a literature review on these three dimensions.

\subsection{Literature on Definition of IT Integration into Teaching}

Chen (2000) argued that learning satisfaction and learning effectiveness depend on a number of key issues: whether the schools are equipped with sufficient computer hardware and software, whether computerized teaching environments are well-planned, whether there are enough computer classrooms, whether teachers and students have sufficient IT literacy and teaching materials are rich.

Wang (2000) evaluated IT integration into teaching and argued that it can be assessed on the basis of human factors (i.e. IT literacy of teachers, students and IT personnel) and environmental factors (i.e. computer classrooms, computers in classrooms, campus networks, the Internet, digital teaching materials and teaching software). These are factors that determine the success of IT integration into teaching.

Chiang (2002) investigated the attitudes of elementary school teachers towards the integration of IT and teaching. He identified four factors influencing educational reform: (1) directions for schools to develop information technology education; (2) attitudes of school deans and principals; (3) whether teachers are involved in the promotion and decision-making of IT integration into teaching; (4) whether school deans, principals and teachers have consistent attitude toward the factors that influence IT integration into teaching.

Chiang (2002) believed that the factors that affect the integration of Internet into teaching can be divided into external and internal factors. External factors include computer software and hardware, school \& administrative support, professional \& technical support, peer group support, curricula and IT literacy of students. Internal factors include the ability of teachers in IT integration into teaching, the motivations, willingness and self-efficacy of teachers and the innovation of teachers (Wu, 2008; Lee, 2011).

In sum, this paper suggests "the use of electronic whiteboards and projectors" and "the use of computerized teaching platform" as the two measureable factors of the variable "IT integration into teaching".

\subsection{Literature on Learning Satisfaction}

Starr (1972) designed a questionnaire on the learning satisfaction of university students by covering five aspects: campus environment and facilities, learning outcomes, administrative measures and services, interpersonal relationships and respect of teachers and administrative staff to students. Tough (1982) indicated that satisfaction is the feelings and attitudes held by students towards learning activities. Happy feelings or active attitudes mean satisfaction. In contrast, unhappy feelings or passive attitudes mean dissatisfaction. Scholars have varying perspectives and research findings regarding the measurement of learning satisfaction. Learning satisfaction is one of the key metrics of learning outcomes. In addition to personal factors of students, teacher, curriculum and learning environment may all affect learning satisfaction of students. Long (1991) believed that the main goals of learning activities for adults are achievements and satisfaction. Teven and McCroskey (1997) suggested that students' perceived concern from teachers has positive influence on their assessments of teachers. Gaziel (1997) argued that school effectiveness depends on school culture, which is related to a school's academic emphasis, continuous improvements and disciplines. Baker, Hansen, Joiner, \& Traum (1999) explored how interaction between teachers and students affect satisfaction with schools. The results showed that the concern and support of teachers to students have positive impact on students' satisfaction with schools. Corts et al. (2000) referred to five environmental factors to explore the factors that affect student satisfaction. The results suggested that career preparation and course offerings are the biggest factors in the determination of students' satisfaction. Meanwhile, advising has positive influence over students' satisfaction. Scholars have varying perspectives and research findings regarding the measurement of learning satisfaction. This paper summarizes the above findings and defines learning satisfaction as the pleasant feelings or attitudes towards learning activities. Learning satisfaction as a main dimension is explored with the following factors:

A. Learning attitude: A stable, psychological tendency students express towards learning and learning scenarios. It 
can usually be determined and explained by the attention, emotions and willpower of students to learning.

B. Learning motivation: The drive to prompt students to learn. Whether students take a proactive attitude and enjoy learning and how well they are doing is directly linked with learning motivations.

C. Learning interest: The enthusiasm that students feel for the subjects they are about to learn. This positive emotion will prompt students to learn autonomously.

\subsection{Literature on Learning Effectiveness}

Learning effectiveness refers to the change in the knowledge, skills and attitudes of students after the completion of teaching (Chiu, 1992; Piccoli, Ahmad, and Ives (2001). Jones (1996) pointed out that learning effectiveness is subject to the influence of learning patterns, curriculum designs and teaching. Loo (1999) also suggested that learning performances are under the influence of learning patters, curriculum designs and teaching. The evaluation of learning effectiveness is generally achieved via students' school grades, the ability to obtain professional certificates and the ability to take external examinations. Therefore, this paper defines learning effectiveness as the students' school grades, professional skills and ability to take external exams after learning. These are also the three sub-dimensions for the metrics of learning effectiveness. Below is a summary of the operational definitions of these sub-dimensions.

A. School grades: Test results at school after students complete the learning process.

B. No. of professional certificates: The number of professional qualification licenses that the students are able to obtain after learning the subjects and acquiring other capabilities at school.

C. External exams: The process in which students take external professional exams after learning the subjects in school.

\subsection{Literature on IT Integration into Teaching and Learning Effectiveness}

Moersch (1995) indicated that the successful integration of IT into teaching depends on whether the teachers are able to combine IT with curricula and willing to change teaching methods. However, whether IT integration into teaching can take root hinges on the emotions, skills and attitudes the teachers have toward IT. The conviction and skillsets of the teachers have a profound impact on the success of IT integration into teaching.

Leggett \& Persichitte (1998) indicated that the barriers to the use of technologies in teaching during the past five decades were time, expertise, access, resources and support (TEARS). Bitner \& Bitner (2002) emphasized that teachers play a pivotal role in the success of IT integration into teaching. Whilst the selection of appropriate equipment and teaching software is the prerequisite, the IT literacy and attitudes of teachers are the key factor to the success of IT integration into teaching. Strehle \& Hausfather (2002) also come up with similar conclusions. Tseng (2012) believed that learning facilities as part of the learning environment exhibits a significant influence on learning satisfaction.

In sum, this paper argues that if teachers can overcome the above barriers on the IT integration into teaching, it will have a positive influence on the learning effectiveness of students. Therefore, this paper develops the following hypothesis:

$\mathrm{H}_{1}$ : IT integration into teaching has a significantly positive influence on learning effectiveness of students.

\subsection{Literature on IT Integration into Teaching and Learning Satisfaction}

Wang (2001) found that the more experienced students are with the Internet, the higher their learning satisfaction and learning performances.

Wu (2008) suggested that IT integration into teaching is significantly and positively correlated with learning interest and learning satisfaction.

Huang (2009) indicated that the appropriate use of IT in teaching and the guidance based on scenarios to ignite learning interest can enhance learning attitudes of students and teaching effectiveness of teachers.

This study argues that if teachers can integrate IT into teaching at the right time, it will have a positive influence on learning satisfaction of students. Therefore, this paper develops the following hypothesis:

$\mathrm{H}_{2}$ : IT integration into teaching has a significantly positive influence on learning satisfaction of students.

\subsection{Literature on Learning Satisfaction and Learning Effectiveness}

Generally speaking, scholars explored the levels of learning satisfaction by looking at four dimensions, i.e. curricula 
and teaching materials, teaching, learning environments and interpersonal relationships (Wei \& Lu, 1993). As far as remote learning is concerned, Biner, Barone, Welsh \&Dean (1997) examined the learning satisfaction of the students in the TV and broadcasting curriculum. The dimensions for learning satisfaction include teacher, technique, procedure management, positioning of the overall personnel, and promptness of data delivery, supporting facilities and contacts with teachers. This paper refers to school grades, learning satisfaction and self-assessments in the questionnaire to evaluate the online learning effectiveness of the respondents. Learning satisfaction is based on the evaluation of students after they have personally experienced all the factors in the learning environment (Piccoli et al., 2001). Self-assessments are the expression of knowledge and capability that learners have acquired with confidence in the form of external behaviour (Piccoli, et al., 2001). Yen and Ho (2001) believed that the application of IT to teaching can boost learning effectiveness of students. However, curriculum content and teaching activities remains the key and IT is just one of the supporting tools. Therefore, this paper develops the following hypothesis:

$\mathrm{H}_{3}$ : Learning satisfaction of students has a significantly positive influence on learning effectiveness of students.

2.7 To the Research Aims, Hypotheses and Literature Review Stated Above, This Paper Comes Up with The Following Research Structure Illustrated in Figure 1:

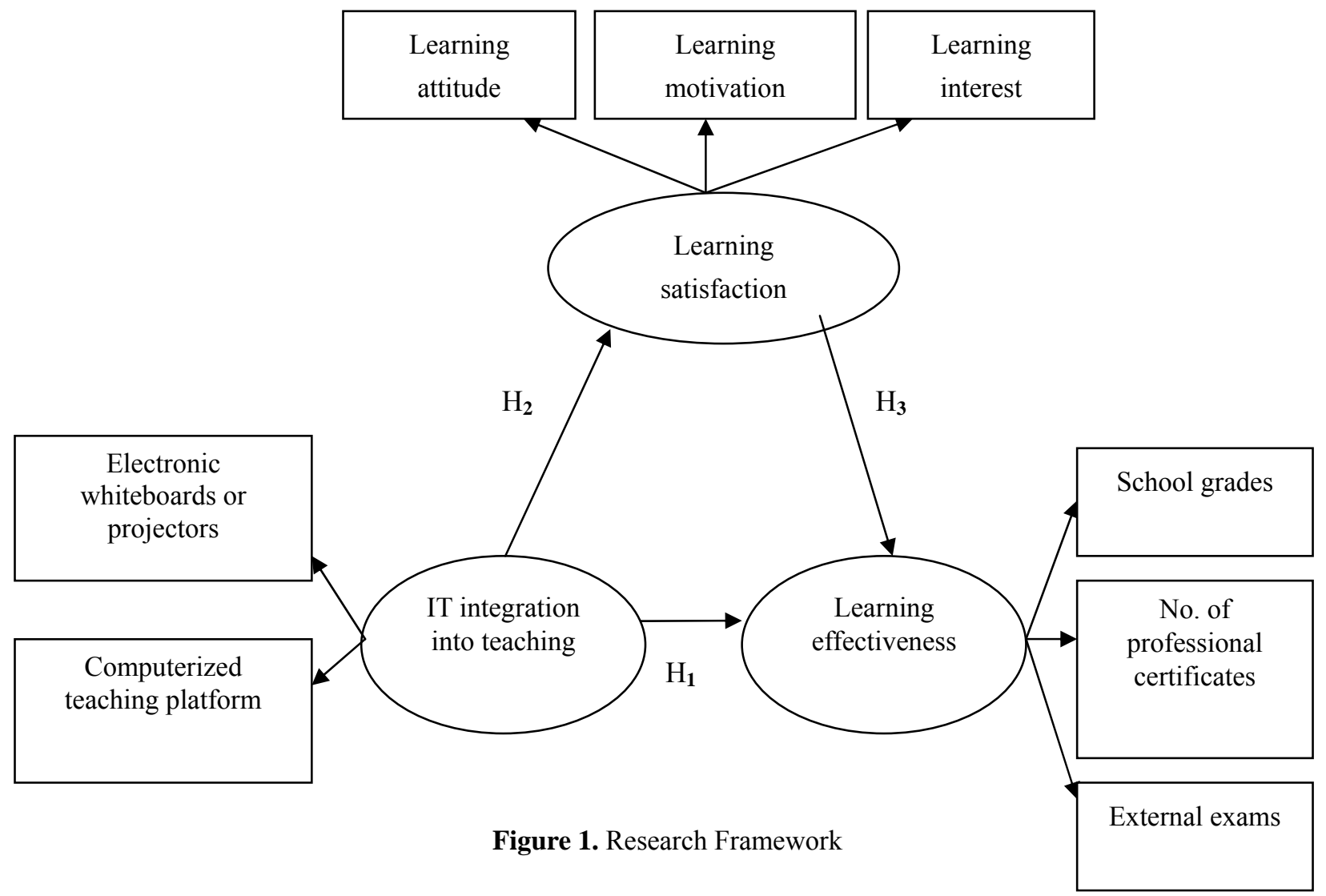

\section{Research Methodology}

\subsection{Subjects of Study and Questionnaire Design}

This study issued questionnaires to the administrative supervisors and teachers in vocational colleges in Taiwan using stratified sampling. To enhance the content validity and reliability of the questionnaire, this study conducts a questionnaire on experts following a pilot test after questionnaire design. Inappropriate questions were either modified or deleted before the post test. This study issues a total of 650 questionnaires and 253 effective ones are returned (or $38.9 \%$ effective recovery rate). Table 1 shows the number of questions for individual dimensions in the structural model (i.e. conceptual dimensions) and the dimensions of the measurement model (i.e. operational measurement dimensions). 


\subsection{CMV (Common Method Variance) Test}

This study confirms that the questionnaire does not exhibit the problems associated with common method variances after CFA tests. The results are shown in Table 2.

\subsection{Linear Structural Equation Model}

Confirmatory factor analysis (CFA) is an analytical method in contrast with EFA (exploratory factor analysis). This study conducts CFA on the pairs of the three key dimensions, i.e. IT integration into teaching, learning satisfaction and learning effectiveness. Linear structural equation modeling (SEM) includes structural modeling and measurement modeling. It can effectively resolve the causal relationship between latent variables. Meanwhile, the validation model this study constructs consists of three elements: (1) whether the overall model is in compliance with goodness-of-fit criteria; (2) the goodness-of-fit of the measurement model; (3) the goodness-of-fit of the structural model.

Table 1. No. of Questions per Dimension

\begin{tabular}{clcl}
\hline imensions of Structural Model & Dimensions of Measurement Model & $\begin{array}{c}\text { No. of } \\
\text { questions }\end{array}$ & \multicolumn{1}{c}{ References } \\
\hline IT integration into teaching & $\begin{array}{l}\text { Electronic whiteboards or projectors } \\
\text { Computerized teaching platform }\end{array}$ & 4 & $\begin{array}{l}\text { Wang (2000); Chiang (2002) } \\
\text { and Chen (2000) }\end{array}$ \\
Learning satisfaction & $\begin{array}{l}\text { Learning attitude } \\
\text { Learning motivation } \\
\text { Learning interest }\end{array}$ & 5 & $\begin{array}{l}\text { Wei \& Lu (1993); Teven and } \\
\text { McCroskey (1997); Corts et al. } \\
\text { (2000) }\end{array}$ \\
Learning effectiveness & $\begin{array}{l}\text { School grades } \\
\text { No. of professional certificates } \\
\text { External exams }\end{array}$ & 5 & $\begin{array}{l}\text { Chiu (1992); Loo (1999); } \\
\text { Piccoli et al., (2001) }\end{array}$ \\
\hline
\end{tabular}

Table 2. CMV Test Results

\begin{tabular}{cccccc}
\hline Model & $\chi^{2}$ & DF & $\Delta \chi^{2}$ & $\Delta$ DF & P \\
\hline Single factor & 1326.3 & 92 & 890.2 & 101 & \multirow{2}{*}{0.002} \\
Multi factors & 436.1 & 193 & & & \\
\hline
\end{tabular}

\section{Research Analysis \& Results}

\subsection{Test of Goodness-of-Fit}

\subsubsection{Test of Overall Goodness-of-Fit}

After the literature review and the sampled data analysis, this study constructs an overall model structure, and according to the recommendation from Hair, Anderson, Tatham \& Black (1998), the measurement for the overall goodness-of-fit consists of three metrics: measures of absolute fit, measurement of incremental fit and measurement of parsimonious fit. Table 3 summarizes the test results on the overall goodness-of-fit (Chen, Fang, Chen \& Chien, 2008).

Table 3. Test on Overall Goodness-of-Fit

\begin{tabular}{lccc}
\hline \multicolumn{2}{c}{ Goodness-of-fit indicators } & Criteria & Research results \\
\hline \multirow{3}{*}{ Absolute fit } & GFI & $>0.9$ & 0.912 \\
& AGFI & $>0.8$ & 0.891 \\
\multirow{3}{*}{ Incremental fit } & RMR & $<0.05$ & 0.022 \\
\multirow{3}{*}{ Parsimonious fit } & NFI & $>0.9$ & 0.913 \\
& CFI & $>0.9$ & 0.904 \\
& PNFI & $>0.5$ & 0.641 \\
& PGFI & $>0.5$ & 0.632 \\
\hline
\end{tabular}




\subsubsection{Measurement Model}

The factor loading of individual latent/implicit variables (of the main dimensions) and manifest/explicit variables (of the sub-dimensions) is to measure the linear correlation between individual manifest/explicit variables and latent/implicit variables. The closer the factor loading is to 1 , the better the measurement variables or the sub-dimensional variables can evaluate the main dimension. All the factor loading values of the sub-dimensions in this study are greater than 0.7 , indicating good reliability. In other words, all the sub-dimensions (explicit variables) in the measurement model can appropriately evaluate the main dimensions (implicit variables). Meanwhile, average variance extracted (AVE) is the calculated explanatory power that implicit variables are accounted for the variance of measured items. The higher the AVE, the greater the reliability and convergent validity of implicit variables are. Usually AVE values should be higher than 0.5 to indicate the explained variance of the dimension is greater than the measured error (Fornell and Larcker, 1981). All the AVE values in this study are greater than 0.5, suggesting high reliability and convergent validity of latent/implicit variables (Table 4 and Figure 2)

Table 4. Intra-Model Measurements and Criteria

\begin{tabular}{|c|c|c|c|c|}
\hline $\begin{array}{l}\text { Dimensions of } \\
\text { Structural Model }\end{array}$ & $\begin{array}{c}\text { Dimensions of } \\
\text { Measurement Model }\end{array}$ & Factor loading & Cronbach's $\alpha$ & $\begin{array}{l}\text { Average } \\
\text { Variance } \\
\text { Extractec }\end{array}$ \\
\hline $\begin{array}{l}\text { IT integration into } \\
\text { teaching }\end{array}$ & $\begin{array}{l}\text { Electronic whiteboards } \\
\text { or projectors } \\
\text { Computerized teaching } \\
\text { platform }\end{array}$ & $\begin{array}{l}.84 \\
.81\end{array}$ & .832 & .631 \\
\hline $\begin{array}{l}\text { Learning } \\
\text { satisfaction }\end{array}$ & $\begin{array}{l}\text { Learning attitudes } \\
\text { Learning motivations } \\
\text { Learning interest }\end{array}$ & $\begin{array}{l}.84 \\
.83 \\
.86\end{array}$ & .844 & .643 \\
\hline $\begin{array}{l}\text { Learning } \\
\text { effectiveness }\end{array}$ & $\begin{array}{l}\text { School grades } \\
\text { No. of professional } \\
\text { certifications } \\
\text { External exams } \\
\end{array}$ & $\begin{array}{l}.82 \\
.81 \\
.85 \\
\end{array}$ & .833 & .634 \\
\hline
\end{tabular}

\subsubsection{Coefficient of Determination}

Coefficient of determination is also known as squared multiple correlation (SMC), the level of explanatory power an independent variable (latent) to a dependent variable (latent). Namely, the $\mathrm{R}^{2}$ value shown in Table 5 indicates that the implicit independent variable has adequate explaining ability on the implicit dependent variable respectively.

Table 5. Path of Coefficients of Determination

\begin{tabular}{lc}
\hline \multicolumn{1}{c}{ Coefficients of Determination } & $\mathrm{R}^{2}$ \\
\hline IT integration into teaching $(\mathrm{X}) \rightarrow$ Learning effectiveness (Y) & 0.34 \\
IT integration into teaching (X) $\rightarrow$ Learning satisfaction (ME) & 0.33 \\
Learning satisfaction $(\mathrm{ME}) \rightarrow$ Learning effectiveness (Y) & 0.38 \\
\hline
\end{tabular}

\subsubsection{Path of Coefficients of Determination of Latent Variables}

After the model has passed the tests on internal goodness-of-fit, this study estimates the standardized coefficients and C.R. values of individual latent/implicit variables (shown in Table 6). The path analysis is illustrated in Figure 2. 
Table 6. Estimated Parameters for Latent Variables

\begin{tabular}{lcccc}
\hline & Estimate & S.E. & C.R. & P value \\
\hline $\begin{array}{l}\text { IT integration into teaching } \longrightarrow \\
\text { Learning effectiveness }\end{array}$ & .563 & .043 & 13.093 & $* * *$ \\
$\begin{array}{l}\text { IT integration into teaching } \longrightarrow \\
\text { Learning satisfaction } \\
\begin{array}{l}\text { Learning satisfaction } \\
\text { Learning effectiveness }\end{array}\end{array}$ & .531 & .021 & 25.286 & $* * *$ \\
\hline
\end{tabular}

Note: $* * *$ indicates C.R. reaching statistical significance $(\alpha=0.001)$

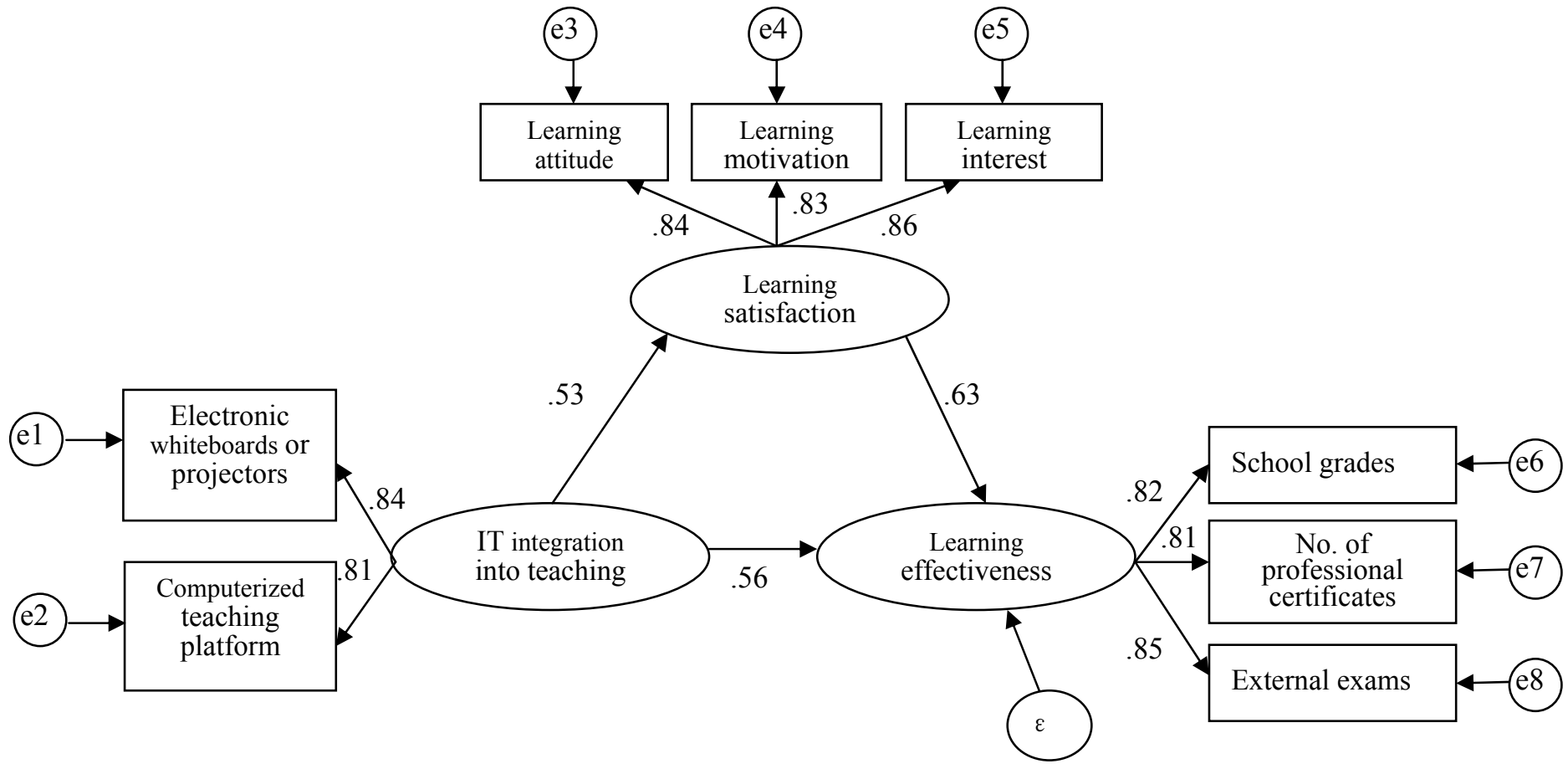

Figure 2. Standardized SEM Analysis

\subsection{Tests on Path Analysis in the Structural Model}

This paper uses Baysian estimations to examine the path coefficients between individual latent (or non-observable) variables in the structural model. This path analysis refers to learning satisfaction (ME) as the mediator (shown in Table 7).

(1) The path coefficient of IT integration into teaching (X) to learning satisfaction (ME) is $\mathrm{H}_{2}=0.53$, with $95 \%$ confidence interval of $0.483,0.642$. It is statistically significant and hence, the first stage effect is significant.

(2) The path coefficient of learning satisfaction (ME) to learning effectiveness ( $\mathrm{Y}$ ) is $\mathrm{H}_{3}=0.63$, with $95 \%$ confidence interval of $0.564,0.721$. It is statistically significant and hence, the second stage effect is significant.

(3) The path coefficient of IT integration into teaching $(\mathrm{X})$ to learning effectiveness $(\mathrm{Y})$ is $\mathrm{H}_{1}=0.56$, with $95 \%$ confidence interval of $0.463,0.663$. It is statistically significant and hence, the third stage effect is significant. 
Table 7. Baysian Estimations

\begin{tabular}{lccccc}
\hline \multicolumn{1}{c}{ Regression weights } & Mean & S.D. & $\begin{array}{c}\text { 95\% Lower } \\
\text { bound }\end{array}$ & $\begin{array}{c}\text { 95\% Upper } \\
\text { bound }\end{array}$ & Name \\
\hline $\begin{array}{l}\text { IT integration into teaching (X) } \rightarrow \\
\text { learning satisfaction (ME) }\end{array}$ & 0.531 & 0.021 & 0.483 & 0.642 & $\mathrm{H}_{2}$ \\
$\begin{array}{l}\text { Learning satisfaction(ME) } \rightarrow \\
\text { Learning effectiveness (Y) }\end{array}$ & 0.634 & 0.031 & 0.564 & 0.721 & $\mathrm{H}_{3}$ \\
$\begin{array}{l}\text { IT integration into teaching (X) } \rightarrow \\
\text { Learning effectiveness (Y) }\end{array}$ & 0.563 & 0.043 & 0.463 & 0.663 & $\mathrm{H}_{1}$ \\
\hline
\end{tabular}

Table 8. Custom Estimates

\begin{tabular}{lcccc}
\hline Numeric Estimates & Mean & S.D. & 95\% Lower bound & 95\% Upper bound \\
\hline Direct effect $\mathrm{H}_{2}$ & 0.531 & 0.021 & 0.461 & 0.641 \\
Direct effect $\mathrm{H}_{3}$ & 0.634 & 0.031 & 0.524 & 0.714 \\
Direct effect $\mathrm{H}_{1}$ & 0.563 & 0.043 & 0.463 & 0.643 \\
Indirect effect $\left(\mathrm{H}_{2} * \mathrm{H}_{3}\right)$ & 0.337 & 0.024 & 0.274 & 0.491 \\
Total effect $\left(\mathrm{H}_{\mathbf{1}}+\mathrm{H}_{2}{ }^{*} \mathrm{H}_{3}\right)$ & 0.900 & 0.033 & 0.807 & 1.021 \\
Direct effect as a percentage of total effect & 0.374 & 0.044 & 0.242 & 0.463
\end{tabular}

According to Table 8:

(1) Indirect effect expressed with the product of $\mathrm{H}_{2}$ and $\mathrm{H}_{3}$ is estimated to be 0.337 , with $95 \%$ confidence interval of 0.274 and 0.491 . It is statistically significant, indicating significant indirect effect. Indirect effect account for $37.4 \%$ of the total effect.

(2) Both indirect effect and direct effect exhibit significantly positive effects. Therefore, learning satisfaction is a partial mediator to the influence of IT integration into teaching on learning effectiveness.

Based on the above analyses, the following conclusions are achieved:

1. IT integration into teaching has significantly positive influence on learning effectiveness in vocational colleges in Taiwan. The standardized estimated parameter is 0.563 . Therefore, $\mathrm{H}_{1}$ is supported.

2. IT integration into teaching has significantly positive influence on learning satisfaction in vocational colleges in Taiwan. The standardized estimated parameter is 0.531 . Therefore, $\mathrm{H}_{2}$ is supported.

3. Learning satisfaction has significantly positive influence on learning effectiveness in vocational colleges in Taiwan. The standardized estimated parameter is 0.634 . Therefore, $\mathrm{H}_{3}$ is supported.

4. The above three conclusions prove the high degree of goodness-of-fit for the model built by this study. Also, learning satisfaction has a certain degree of mediating effects on the students in vocational colleges in Taiwan. This finding is consistent with the partial mediating effects argued by Baron and Kenny (1986) that the original relationship between the independent variable and the dependent variable is undermined with the incorporation of the mediator.

\section{Conclusions and Suggestions}

Based on the above analysis and results, this study makes the following contributions and summarizes its contributions. Finally, it presents the research limitations and suggestions for follow-up studies.

\subsection{Conclusion}

This study surveys the administrative supervisors and teachers in the vocational colleges in Taiwan and constructs SEM models to validate the effects of IT integration to teaching on learning effectiveness, with learning satisfaction as the mediator. Below is the list of the research findings. 


\subsubsection{Effects of IT Integration into Teaching on Learning Effectiveness}

The results supports $\mathrm{H} 1$ that IT integration into teaching has a significantly positive influence on learning effectiveness. This result is consistent with Moersch (1995), Leggett \& Persichitte (1998), Bitner \& Bitner (2002) and Tseng (2012).

In other words, students in Taiwanese vocational schools and colleges learn more effectively when their teachers employ electronic whiteboards, projectors, and computerized teaching platforms. The incorporation of technology into teaching should be encouraged. In order to increase students' learning effectiveness, schools should invest more in regularly updating their teaching equipment.

\subsubsection{Effects of IT Integration into Teaching on Learning Satisfaction}

The results supports H2 that IT integration into teaching has significantly positive influence on learning satisfaction. This result is consistent with Wang (2001), Wu (2008) and Huang (2009).

In other words, the results show that utilizing electronic whiteboards, projectors, and computerized teaching platform in colleges and vocational schools in Taiwan greatly improves students' learning satisfaction, attitude, motivation and interest. Since information technology can considerably boost students' learning satisfaction, it is a wise educational policy to promote the use of information technology as a teaching tool.

\subsubsection{Effect of Learning Satisfaction on Learning Effectiveness}

The research results support H3, i.e. learning satisfaction has a significantly positive influence on learning effectiveness. This result is consistent with Biner et al. (1997) \& Piccoli et al. (2001).

In other words, the results demonstrate that students' learning attitude, motivation and interest are closely related to their academic performance at school, to the number of licenses they obtain and to their success in other professional qualification exams. From this research we discover three important correlations: (1) The integration of information technology and teaching positively influences students' learning satisfaction. (2) Students' satisfaction positively influences their learning effectiveness. (3) The integration of information technology and teaching positively influences learning effectiveness. An important conclusion emerges from these three correlations: learning satisfaction is a very important mediating factor, rather than a complete mediator.

\subsection{Research Contributions}

1. The results of this paper can encourage and inspire the business world to integrate IT into teaching in order to boost the learning effectiveness of students via bettered learning satisfaction.

2. Previous studies on the IT integration into teaching and learning effectiveness in vocational colleges in Taiwan focus on EFA (exploratory factor analysis). However, this paper constructs a model by combining past academic results and validating the overall goodness-of-fit of the model. Hence, it is an important empirical study on the basis of CFA (confirmatory factor analysis). Future studies are suggested to dig further on the relevant topics.

3. The dimensional indicators constructed and validated by this study are the key to competitive advantages for schools. They can serve as a reference for the college administration in important decision-making.

\subsection{Research Limitations}

This paper uses stratified sampling on the population and as a result, the sample recovery rate is somewhat low and may not be able to represent the population. This is the biggest research limitation of this paper.

\subsection{Suggestions for Future Studies}

This study examines the correlation between IT integration into teaching, learning satisfaction and learning effectiveness by constructing a model with one cause, one effect and one mediator. Future studies can extend on top of the research model in this paper by constructing a model with one cause, one effect and multiple mediators, or a model with one cause, one effect and one intervening factor, or with one intervening mediator and a mediator model and conduct CFA for in-depth results. 


\section{References}

Baker, M., Hansen, T., Joiner, R., \& Traum, D. (1999). The role of grounding in collaborative learning tasks, in P. Dillenbourg(Ed.), Collaborative Learning: Cognitive and Computational Approaches, (pp. 31-63). Amsterdam: Pergamon / Elsevier Science.

Baron, R. M., \& Kenny, D. A. (1986). The moderator-mediator variable distinction in social psychological research: Conceptual, strategic, and statistical considerations. Journal of Personality and Social Psychology, 51, 1173-1182. http://dx.doi.org/10.1037/0022-3514.51.6.1173

Biner, P., Barone, N., Welsh, K., \& Dean, R. (1997). Relative academic performance and its relation to facet and overall satisfaction with interactive telecourses. Distance education, 18(2), 318. http://dx.doi.org/10.1080/0158791970180208

Bitner, N., \& Bitner, J. (2002). Integrating technology into the classroom: Eight keys to success. Journal of Technology and Teacher Education, 10(1), 95-100.

Chen, F., Fang, H. K., Chen, K.C., \& Chien, A.J. (2008). A Study of Relationship on Organizational Culture, Intellectual Capital and Organizational Performance. Journal of Chinese Economic Research, 6, 146-168.

Chen, Y. (2000). Difficulties and Challenge of Integrating Computers into Teaching. Information \& Education, 77, 29-35.

Chiang, L. (2002). A Study on Elementary School Teachers' Concern about the Innovation of Integrating Information Technology into Classroom Teaching, Master's degree thesis, Graduate Institute of Science Education for Primary School, Hualien Teachers College, Taiwan.

Chiu, G. (1992). Philosophy and Development of Computer-Assisted Learning. Instructional Technology \& Media, 13, 15-22.

Corts, D. P., Lounsbury J. W., Saudargas R. A., \& Tatum H. E. (2000). Assessing Undergraduate Satisfaction with an Academic Department: A Method and Case Study. College Student Journal, 34(3), 399-408.

Fornell, C. R., \& Larcker, F. F. (1981). Structural Equation Models with Unobservable Variables and Measurement Error. Journal of Marketing Research, 18, 39-51. http://dx.doi.org/10.2307/3151312

Gaziel, H. (1997). Impact of School Culture on Effectiveness of Secondary Schools with Disadvantaged Students. Journal of Educational Research, 90(5), 310-319. http://dx.doi.org/10.1080/00220671.1997.10544587

Hair, J. F., Anderson, R. E., Tatham, R. L., \& Black, W. C. (1998). Multivariate Data Analysis (5th ed), Upper Saddle River, NJ: Practice Hall.

Huang, M. Y. (2009). The Investigation of the Problem-based Learning Strategy with Computer Enhance Technique on High School Students' Health-related Fitness Learning Attitude. Bulletin of Physical Education, 42(4), $87-100$.

Jones, B. L. (1996). Self-Efficacy and Personal Goals In Classroom Performance: The Effect of Task Experience. Ph.D. Thesis, Graduate School of Management, Kent State University.

Lee, Y. J. (2011). A Case Study on the Effect of Teaching Innovation on Learning Effectiveness: Using a Moderator of" Integrating Information Technology into Teaching. Journal of Human Resources \& Adult Learning, 7(1), 34.

Leggett, W. P., \& Persichitte, K. A. (1998). Blood, sweat, and TEARS: 50 years of technology implementation obstacles. Tech Trends: For Leaders in Education and Training, 43(3), 33-36. http://dx.doi.org/10.1007/BF02824053

Long, H. B. (1991). Continuing Higher Education Research Futures: A Delphi Study of Professors of Adult Education. The Journal of Continuing Higher Education, 39(2), 29-35. http://dx.doi.org/10.1080/07377366.1991.10400813

Loo, R. (1999). Confirmatory Factor Analyses of Kolb's Learning Style. British Journal of Educational Psychology, 69, 213-219. http://dx.doi.org/10.1348/000709999157680

Moersch, C. (1995). Levels of technology implementation (LoTi): A framework for measuring classroom technology use. Learning and Leading with Technology, 23(3), 40-42.

Piccoli, G., Ahmad, R., \& Ives, B. (2001). Web-based Virtual Learning Environments: A Research Framework and a preliminary assessment of effectiveness in basic skills IT training. MIS Quarterly, 25(4), 401-426. 
http://dx.doi.org/10.2307/3250989

Starr, A. (1972). College Student Satisfaction Questionnaire (CSSQ) Manual, Eric Document Reproduction Service. No. ED 058268.

Strehle, E. L., \& Hausfather, S. J. (2002). Narratives of collaboration: Inquiring into technology integration in teacher education. Journal of Technology and Teacher Education, 10(1), 27-47.

Teven, J. J., \& McCroskey, J. C. (1997). The Relationship of Perceived Teacher Caring with Student Learning and Teacher Evaluation. Communication Education, 46(1), 1-9. http://dx.doi.org/10.1080/03634529709379069

Tough, A. (1982). Some major reasons for learning. (Eric Document Reproduction Service No. ED 033 251)

Tseng, Y. (2012). A Study of Learning Satisfaction on Integration. Electronic Storybook Creation into English Teaching in Junior High Schools, Master's degree thesis, Department of Information Communication, University of Kang Ning, Taiwan.

Wang C. H. (2001). A study of the Learning Behavior, Satisfaction and Performance on Internet Learning. Master's thesis, Department of Information Management, Da-Yeh University, Taiwan.

Wang, C. S. (2000). A Study of the Implementation and Evaluation for Information Technology Integrated Instruction. Information and Education, 80, 23-31.

Wei, S., \& Lu, M. (1993). A Study of the Factors Influencing the Students' Rating Responses and Satisfaction of Instruction. Taipei Medical University Institutional Repository, 22(2), 153-178.

Wu, T. (2008). A Study of the Relationship between Learning Interest and Learning Satisfaction of Information Integrated Teaching, A Case Study on Chiayi, Master's thesis, Department of Industrial Education \& Technology, National Changhua University of Education, Taiwan.

Yen, Y. C., \& Ho, R. G. (2001). Integrated Information Technology in Teaching in Health and Physical Education, Taiwan. New Horizon Bimonthly for Teachers, 112, 71-75. 